\title{
Article \\ Effects of Aging Treatment on Corrosion Behavior of a Tensile Deformed Al-Cu-Mn-Fe-Zr Alloy in 3.5\% NaCl Solution
}

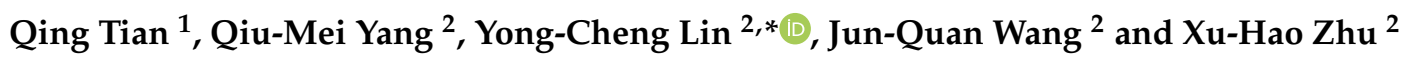 \\ 1 Department of Electronic Science, Huizhou University, Huizhou 516007, China; jinhanlin830@sina.com \\ 2 School of Mechanical and Electrical Engineering, Central South University, Changsha 410083, China; \\ Xianyangwu88@163.com (Q.-M.-Y.); jinlongzhang1986@163.com (J.-Q.W.); mschen77@163.com (X.-H.Z.) \\ * Correspondence: yclin@csu.edu.cn
}

check for updates

Citation: Tian, Q.; Yang, Q.-M.; Lin, Y.-C.; Wang, J.-Q.; Zhu, X.-H. Effects of Aging Treatment on Corrosion Behavior of a Tensile Deformed $\mathrm{Al}-\mathrm{Cu}-\mathrm{Mn}-\mathrm{Fe}-\mathrm{Zr}$ Alloy in 3.5\% NaCl Solution. Materials 2021, 14, 5062. https://doi.org/10.3390/ma14175062

Academic Editor: Luigi Calabrese

Received: 7 July 2021

Accepted: 1 September 2021

Published: 3 September 2021

Publisher's Note: MDPI stays neutral with regard to jurisdictional claims in published maps and institutional affiliations.

Copyright: (c) 2021 by the authors. Licensee MDPI, Basel, Switzerland. This article is an open access article distributed under the terms and conditions of the Creative Commons Attribution (CC BY) license (https:/ / creativecommons.org/licenses/by/ $4.0 /)$.

\begin{abstract}
In this paper, the effects of an aging treatment on the corrosion resistance/mechanism of a tensile deformed $\mathrm{Al}-\mathrm{Cu}-\mathrm{Mn}-\mathrm{Fe}-\mathrm{Zr}$ alloy are investigated. The impedance magnitude and polarization resistance increase, while the corrosion current decreases with the increased aging time and temperature. The discontinuously-distributed precipitates and precipitation-free zone, which can cut the corrosion channels, appear at grain boundaries when the temperature is relatively high and the aging time is relatively long. They can improve the corrosion resistance. Additionally, the intergranular and pitting corrosion are the main mechanisms. The intergranular corrosion is likely to occur in an under-aged alloy. This is because the potential difference between the grain boundaries and grains is high, due to the segregation of $\mathrm{Cu}$ atoms. When the aging degree is increased, the grain boundary precipitates reduce the potential difference, and the intragranular precipitates make the surrounding matrix prone to dissolution. As such, the pitting corrosion is likely to occur in the over-aged alloys.
\end{abstract}

Keywords: alloy; aging; corrosion mechanism; microstructure

\section{Introduction}

Because of their outstanding mechanical and physical properties, aluminum alloys are widely used in the fields of ship building and aerospace [1-4]. Al-Cu alloys are often used in the production of high-performance components, such as rocket engines, and pressure vessels, etc. These components are thin-walled and large-sized, and usually formed by tensile deformation [5-8]. Al alloys have been also selected as the building material for space habitats and equipment. Generally, the service environment of the components is severe. The alloys or components should have excellent mechanical and corrosion properties [9-13]. Therefore, it is important to design suitable heat treatment methods to enhance the mechanical and corrosion properties of $\mathrm{Al}-\mathrm{Cu}$ alloys.

In recent years, many scholars have studied the effects of aging on the precipitation kinetics [14,15], corrosion resistance [16-18], as well as some other mechanical properties of Al-Cu alloys [19-24]. However, the corrosion performance of Al-Cu alloys still needs comprehensive investigation. Lin et al. [25] and Li et al. [26] investigated the relationship between the corrosion behavior and microstructures of 2024Al alloy. In their study, de Sousa Araujo et al. [27] revealed the effects of thermomechanical treatments on the corrosion behavior of a $2198 \mathrm{Al}-\mathrm{Cu}-\mathrm{Li}$ alloy. Wang et al. [28] discussed the effects of the S phase on the pitting initiation of an Al-Cu-Mg alloy. Ma et al. [29] significantly enhanced the corrosion resistance of $2219 \mathrm{Al}$ alloy welds by laser surface melting. Liu et al. [30] indicated that the effect of microstructure refinement on corrosion performance is weak, but the effect of second phases is significant. Surekha et al. [31] found that the dissolution of the $\mathrm{Al}_{2} \mathrm{Cu}$ phase can improve the corrosion resistance of a $2219 \mathrm{Al}$ alloy. Lu et al. [32] found that pre-deformation can increase the $\theta^{\prime}$ phase within grains and improve the corrosion resistance of a 2219 alloy. Huang et al. [33] found the phases at grain boundaries 
can reduce the intergranular corrosion sensitivity of an Al-Cu-Li alloy. Grilli et al. [34] indicated that the intermetallics act as a cathode in the corrosion process, dissolving the surrounding aluminum matrix. Chen et al. [35] found the multiaxial fatigue life decreases with the increased pre-corrosion time. Hikku et al. [36] improved the corrosion resistance by adding graphene nanocomposite coating and chromium plating on a $2219 \mathrm{Al}$ alloy surface. Kairy et al. [37] found that adding $\mathrm{Zr}$ and Sc elements to Al-Cu alloys can reduce the corrosion current, thereby reducing the pitting/intergranular corrosion. Zhu et al. [38] improved the corrosion resistance of the alloy welds by heat treatment. Emarati et al. [39] improved the corrosion resistance of a $2024 \mathrm{Al}$ alloy by electric etching, anodizing, sealing and surface chemical modification.

Although there is some research on the mechanical and corrosion properties of $\mathrm{Al}-\mathrm{Cu}$ alloys, there are few studies on the effects of an aging treatment on the corrosion properties, as well as the corrosion mechanisms, of a deformed Al-Cu-Mn-Fe- $\mathrm{Zr}$ alloy. Furthermore, this topic is very important for industrial production components, such as thin-walled components produced by tensile deformation or spinning processing. In this study, a tensile deformed Al-Cu-Mn-Fe-Zr alloy is aged at $155-175^{\circ} \mathrm{C}$ for $6-24 \mathrm{~h}$. The electrochemical corrosion experiments were performed in a $3.5 \% \mathrm{NaCl}$ solution. The electrochemical impedance spectroscopy (EIS) and polarization curves of the aged alloy are measured in order to discuss the effects of aging on corrosion resistance. To discuss corrosion mechanisms, the corrosion properties and corrosion morphology of the aged alloy are analyzed.

\section{Materials and Experiments}

\subsection{Materials Preparation}

A rolled Al-Cu-Mn-Fe-Zr alloy sheet with the chemical compositions of (Al-6.37Cu$0.30 \mathrm{Mn}-0.16 \mathrm{Fe}-0.12 \mathrm{Zr}-0.05 \mathrm{Si}-0.04 \mathrm{Ti}$ (wt.\%)), was used. Firstly, the alloy sheet was solutiontreated at the temperature and time of $535^{\circ} \mathrm{C}$ and $40 \mathrm{~min}$, respectively. The tensile test specimens were cut from the solution-treated sheet (in the rolling direction). According to the GB/T4338-2006 "Metal Material High Temperature Tensile Test Method", the tensile test specimens meeting the requirements were then obtained through CNC machining, as shown in Figure 1. The specimens were then stretched on the MTS-GWT2105 testing machine at $150{ }^{\circ} \mathrm{C}$, with a deformation amount of $15 \%$, and tensile speed of $0.54 \mathrm{~mm} / \mathrm{min}$. Afterwards, the specimens were cooled to room temperature in the air. Finally, the deformed specimens were aged according to the designed conditions shown in Table 1.

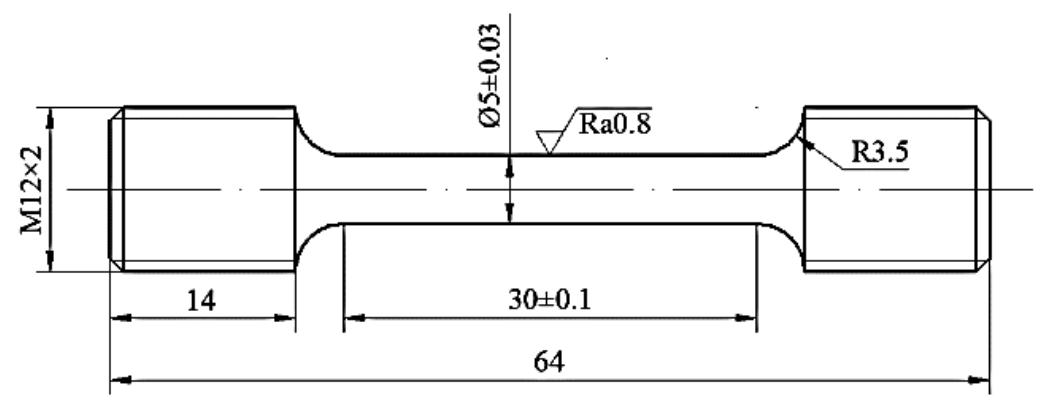

Figure 1. Specific dimensions of tensile test specimen (unit: $\mathrm{mm}$ ).

Table 1. Aging treatment parameter.

\begin{tabular}{ccc}
\hline Case ID & Temperature $\left({ }^{\circ} \mathbf{C}\right)$ & Time (h) \\
\hline 1 & & 6 \\
2 & 155 & 12 \\
3 & & 24 \\
4 & & 6 \\
5 & 175 & 12 \\
6 & & 24 \\
\hline
\end{tabular}




\subsection{Electrochemical Corrosion Experiments}

The electrochemical corrosion experiments were performed on the CHI660E electrochemical workstation. The samples, with a length of $10 \mathrm{~mm}$, were cut from the gauge segment of the aged alloy, and the impurities and oxide film were removed from surface by polishing. The surface area of the samples that were exposed to the $3.5 \% \mathrm{NaCl}$ solution was $40 \mathrm{~mm}^{2}$. Firstly, the samples were immersed in solution for $10 \mathrm{~min}$ to obtain open circuit potential. The electrochemical impedance spectroscopy (EIS) measurements were then conducted with an alternating current (AC) signal, of which the frequency ranged from $0.01 \mathrm{~Hz}$ to $100 \mathrm{KHz}$ and the amplitude was $10 \mathrm{mV}$. In addition, the preparation of the samples for the polarization curve tests are consistent with the EIS test. The scan interval was selected according to the open circuit potential. Based on previous research [29], the open circuit potential of a $2219 \mathrm{Al}$ alloy is between $-0.6 \mathrm{~V} / \mathrm{SCE}$ and $-0.8 \mathrm{~V} / \mathrm{SCE}$. The scanning interval was $-1.2 \sim 0 \mathrm{~V} / \mathrm{SCE}$, and scanning rate was $0.5 \mathrm{mV} \mathrm{s}^{-1}$.

\subsection{Corrosion Morphology Observation}

In order to investigate the effects of the aging treatment on corrosion morphology, a scanning electron microscope (SEM) (FEI Electron Optics B.V; Prague, Czech Republic), optical microscope (OM), and laser scanning confocal microscope (LSCM) were used. Before the SEM and LSCM tests, the non-working surface of specimens was polished to ensure flatness, and the samples were vacuum sealed to avoid the oxidation of corrosion products. In order to analyze the corrosion depth of the longitudinal section of the corroded sample, the OM tests were conducted on an optical microscope (Olympus DSX500) (Olympus Corporation, Tokyo, Japan). Before the OM tests, the longitudinal profile was mechanically polished until the surface had no obvious scratches. In addition, a transmission electron microscope (TEM) (Tecnai G2 F20; FEI Company; Hillsboro, OR, USA) was used to observe precipitated phases in the aged alloy. Here, a TEM sample was obtained by mechanical grinding and stamping. Its thickness was $50-80 \mu \mathrm{m}$ and the diameter was $3 \mathrm{~mm}$. Afterwards, the samples were electropolished by double-jet in $\mathrm{HNO}_{3}(30 \%)$ and $\mathrm{CH}_{3} \mathrm{OH}(70 \%)$ at $-25^{\circ} \mathrm{C}$.

\section{Results and Discussion}

\subsection{Effect of Aging Parameters on Electrochemical Impedance Spectroscopy}

Figure 2 shows the EIS of the aged alloy. In Figure 2a, the curve has an obvious impedance arc at $155^{\circ} \mathrm{C}$ for $6 \mathrm{~h}$. When the aging time is $12 \mathrm{~h}$ or $24 \mathrm{~h}$, two impedance arcs appear at the frequency of $0.01-1 \mathrm{~Hz}$ or $1-1000 \mathrm{~Hz}$, respectively. The arc at the low frequency is mainly caused by the electrochemical corrosion process, while the arc at the high frequency is related to the charge transfer resistance at the interfaces between the electrolyte solution and alloy [40,41]. Generally, a large impedance arc indicates a high impedance magnitude. The impedance magnitude reflects the charge transfer ability of the sample surface. The higher impedance magnitude indicates that the electrode reaction is slower and the corrosion resistance is larger [42-44]. As shown in Figure 2b, the impedance magnitude increases with the extended aging time at a low frequency, showing that the corrosion resistance of the alloy is improved. As shown in Figure 2c, d, the effect of the aging time on the impedance magnitude is consistent with those shown in Figure 2a,b, which further indicates that the corrosion resistance becomes larger with the increased aging time. In Figure 2a,c, the radius of the impedance arc increases as the temperature is raised from $155^{\circ} \mathrm{C}$ to $175^{\circ} \mathrm{C}$ for the same aging time. Meanwhile, in Figure $2 b, d$, the impedance magnitude also shows the same rule, which indicates that the corrosion resistance increases with the raised aging temperature. 


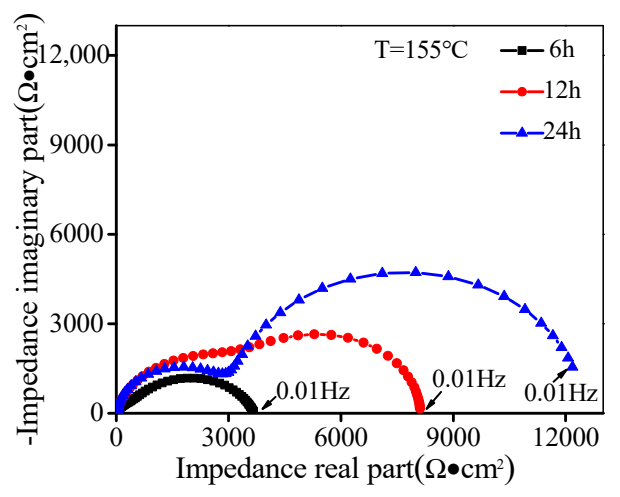

(a)

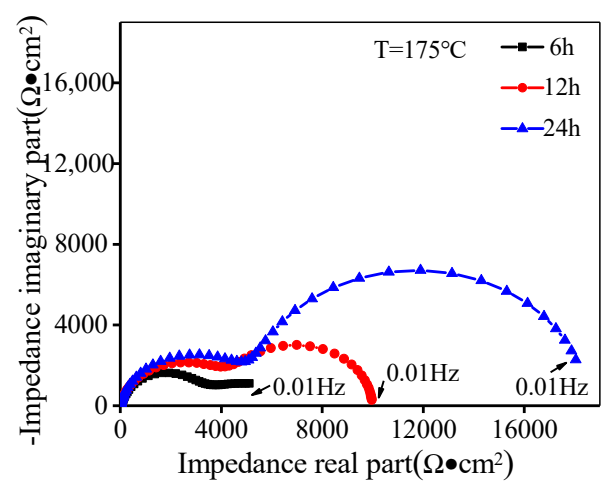

(c)

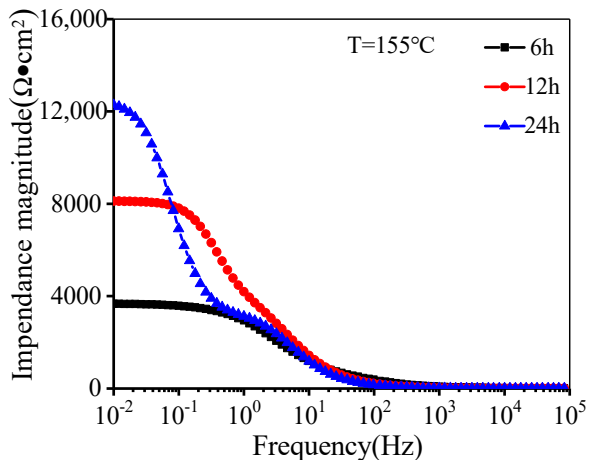

(b)

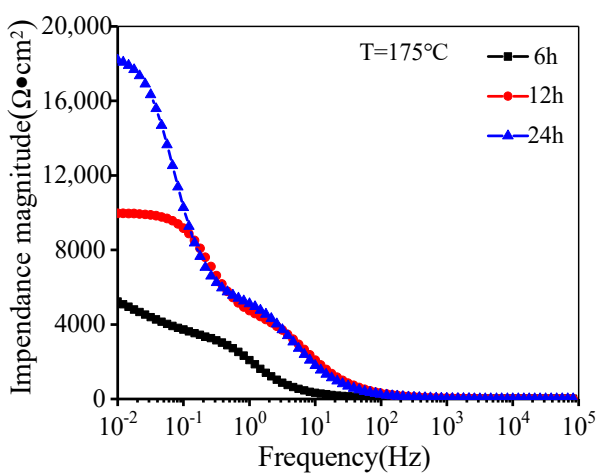

(d)

Figure 2. Electrochemical impedance spectroscopy: (a) Nyquist plots $\left(\mathrm{T}=155^{\circ} \mathrm{C}\right)$; (b) Bode diagrams $\left(\mathrm{T}=155^{\circ} \mathrm{C}\right) ; .(\mathbf{c})$ Nyquist plots $\left(\mathrm{T}=175^{\circ} \mathrm{C}\right) ;(\mathbf{d})$ Bode diagrams $\left(\mathrm{T}=175^{\circ} \mathrm{C}\right)$.

\subsection{Establishment of Equivalent Circuit}

The interface between the alloy and electrolyte solution is generally composed of oxide film, which includes two layers. The outer layer has many small holes, while the inner layer is dense, as shown in Figure 3a [44]. According to the characteristics of oxide film, it can be divided into a porous layer and a barrier layer $[45,46]$ (Figure 3a). The alloy and electrolyte solution can be simplified into an equivalent circuit. In this work, the $\mathrm{R}(\mathrm{Q}(\mathrm{R}(\mathrm{QR}))$ ) model (Figure $3 \mathrm{~b})$ is used. $\mathrm{R}_{\mathrm{s}}$ represents the resistance of the electrolyte solution, and its value mainly depends on the concentration of the electrolyte solution and the distance between the electrodes. $R_{1}$ is the resistance of the porous layers. Additionally, $\mathrm{R}_{2}$ represents the charge transfer resistance, which corresponds to the barrier layers of oxide film. The constant phase element $(\mathrm{Q})$ is used to describe the nonideal capacitance due to non-uniformed oxide film. $Q_{1}$ and $Q_{2}$ are the constant phase elements of the porous and the barrier layers, respectively. The impedance of constant phase elements can be expressed as [47],

$$
Z=Y^{-1}(j \omega)^{-n}
$$

where $Y$ represents the capacitance, $\omega$ is the angular frequency, $\mathrm{n}$ is the dispersion value of the constant phase element, and its value is between -1 and 1 . When $-1<\mathrm{n}<0,0<\mathrm{n}<0.5$, and $0.5<\mathrm{n}<1$, the constant phase element is close to the inductance, resistance, and capacitance, respectively. 


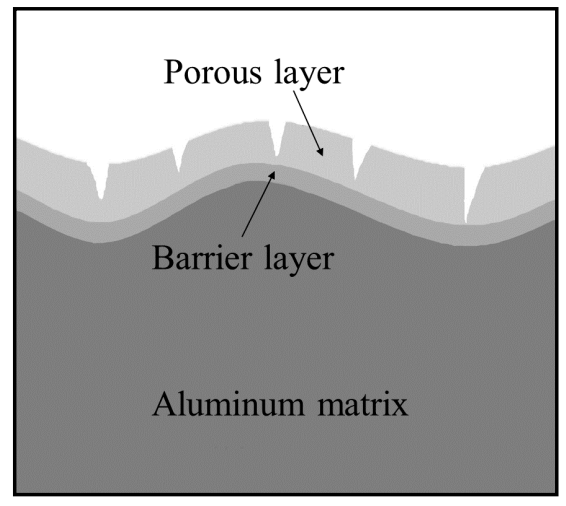

(a)

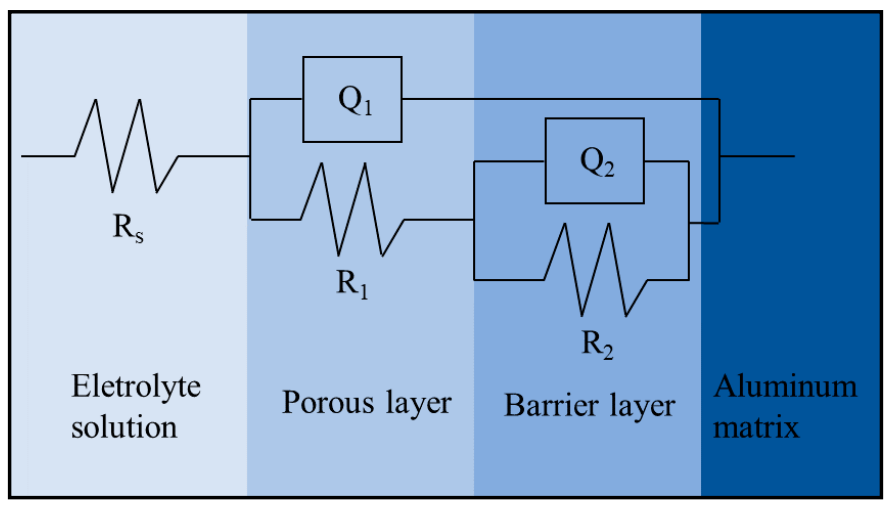

(b)

Figure 3. Schematic diagram of: (a) surface structure; (b) equivalent circuit.

The electrochemical parameters are obtained by ZsimpWin software (v3.60), as shown in Table 2. $R_{S}$ varies little at different conditions, and its value range is $5-11\left(\Omega \cdot \mathrm{cm}^{2}\right)$. As mentioned above, the value of $R_{S}$ is mainly related to the concentration of the electrolyte solution and the distance between the electrodes. Therefore, the aging process has little effect on $R_{s}$. Meanwhile, there is no obvious law in $Q_{1}$ and $Q_{2}$ at different conditions. The phenomenon shows that the oxide film is relatively non-uniform The dispersion values of the constant phase elements (n) are all above 0.5 , and some values are 1 , indicating its electrochemical characteristics are close to the ideal capacitance. However, $\mathrm{n}_{2}$ is 0.596 for the alloy aged at $155^{\circ} \mathrm{C}$ for $6 \mathrm{~h}$, which means that the charge diffusion occurs during the electrochemical corrosion.

Table 2. Parameter fitting results of equivalent circuits.

\begin{tabular}{|c|c|c|c|c|c|c|c|c|}
\hline \multirow{2}{*}{ Temperature $\left({ }^{\circ} \mathrm{C}\right)$} & \multirow{2}{*}{ Time (h) } & $\mathbf{R}_{\mathrm{S}}$ & $\mathrm{Q}_{1}$ & \multirow{2}{*}{$\mathrm{n}_{1}$} & \multirow{2}{*}{$\begin{array}{c}R_{1} \\
\left(\Omega \cdot \mathrm{cm}^{2}\right)\end{array}$} & \multirow{2}{*}{$\begin{array}{c}\mathrm{Q}_{2} \\
\left(\mu \mathrm{F} \cdot \mathrm{cm}^{-2}\right)\end{array}$} & \multirow{2}{*}{$\mathbf{n}_{2}$} & \multirow{2}{*}{$\frac{R_{2}}{\left(\Omega \cdot \mathrm{cm}^{2}\right)}$} \\
\hline & & $\left(\Omega \cdot \mathrm{cm}^{2}\right)$ & $\left(\mu \mathrm{F} \cdot \mathrm{cm}^{-2}\right)$ & & & & & \\
\hline \multirow{3}{*}{155} & 6 & 6.435 & 0.89 & 1 & 0.123 & 48.42 & 0.596 & 3932 \\
\hline & 12 & 5.92 & 16.43 & 0.874 & 4523 & 10.84 & 1 & 3638 \\
\hline & 24 & 5.14 & 15.91 & 0.8 & 34.13 & 276.9 & 0.8 & 9077 \\
\hline \multirow{3}{*}{175} & 6 & 10.4 & 73.59 & 0.761 & 59.6 & 23.3 & 0.933 & 4617 \\
\hline & 12 & 7.14 & 9.503 & 0.904 & 4930 & 1397 & 0.994 & 5072 \\
\hline & 24 & 8.633 & 11.62 & 0.909 & 5785 & 203.9 & 0.994 & 12,750 \\
\hline
\end{tabular}

The sum of $R_{1}$ and $R_{2}$ is the polarization resistance $\left(R_{p}\right)$, which can represent the corrosion resistance of the studied alloy. Generally, it is believed that the corrosion current during electrochemical corrosion decreases with the increased $R_{p}$, i.e., the corrosion resistance becomes increasingly larger. The values of $R_{p}$ are shown in Figure 4 . It can be observed the polarization resistance increases with the increased aging time and temperature.

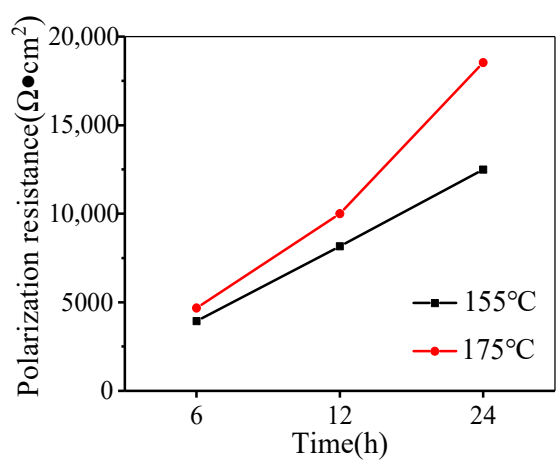

Figure 4. Polarization resistance $\left(\mathrm{R}_{\mathrm{p}}\right)$ under different aging conditions. 


\subsection{Effect of Aging Parameters on Polarization Curves}

Figure 5 shows the polarization curves of the aged alloy. The polarization curves are similar under different aging conditions, and there is no obvious passivation. This is because $\mathrm{Cl}^{-}$is adsorbed on the surface of the alloy, and the formation of the passivation film is hindered [48-50]. The values of corrosion potential, corrosion current, as well as the slope of cathode and anode, are measured using the Tafel extrapolation method [45,51], as shown in Table 3. The corrosion potential decreases slightly with the increased aging time at $155^{\circ} \mathrm{C}$. When the aging temperature is raised to $175^{\circ} \mathrm{C}$, the corrosion potential changes irregularly at a different aging time. The corrosion potential reflects the possibility of electrochemical corrosion of the alloy [52-54], but the law of corrosion potential change is not obvious under the tested conditions. Generally, the corrosion dynamic parameters are used to characterize the corrosion resistance of alloys. Moreover, the corrosion current belongs to the category of corrosion dynamic parameters [55]. As such, this research selects the corrosion current as the judgment standard. The corrosion current is reduced by $90.23 \%$ at $175{ }^{\circ} \mathrm{C}$ when the aging time is increased from $6 \mathrm{~h}$ to $24 \mathrm{~h}$. The corrosion current is reduced from 0.394 to 0.183 (i.e., a decrease of $53 \%$ ), as the aging temperature is raised from 155 to $175^{\circ} \mathrm{C}$ at the aging time of $24 \mathrm{~h}$. In summary, the corrosion current decreases with the raised temperature and aging time, i.e., the corrosion resistance of the alloy increases.

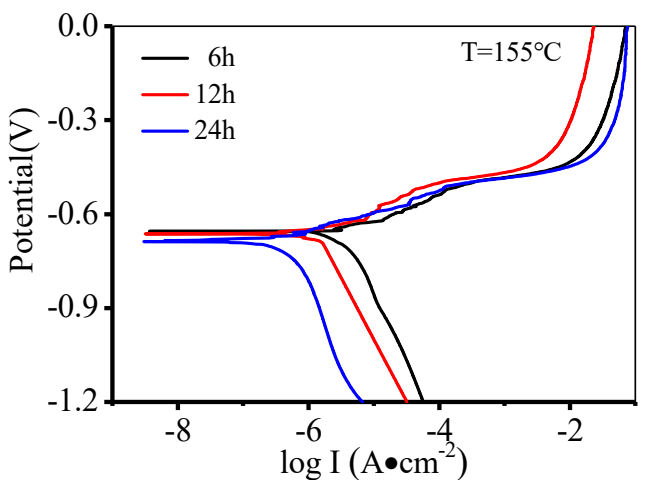

(a)

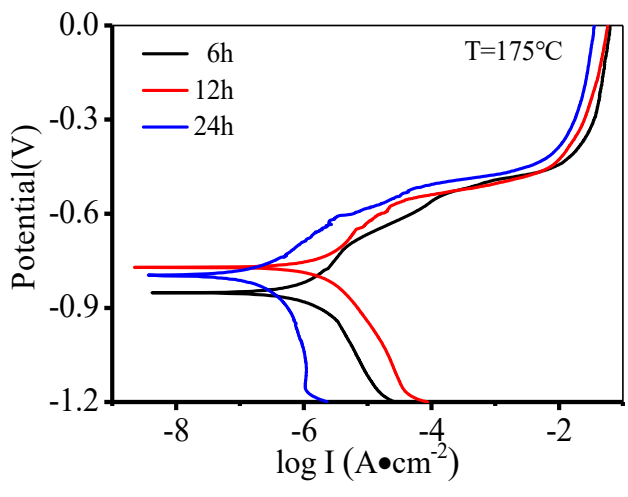

(b)

Figure 5. Polarization curves at: $(\mathbf{a}) \mathrm{T}=155^{\circ} \mathrm{C}$; (b) $\mathrm{T}=175^{\circ} \mathrm{C}$.

Table 3. Corrosion parameters of the alloy under different aging conditions.

\begin{tabular}{cccc}
\hline Temperature & Time & Corrosion Potential & Corrosion Current \\
\hline$\left({ }^{\circ} \mathbf{C}\right)$ & $\mathbf{( h )}$ & $\mathbf{( V )}$ & $\left(\mu \mathrm{A} / \mathbf{c m}^{2}\right)$ \\
\hline \multirow{2}{*}{155} & 6 & -0.655 & 2.747 \\
& 12 & -0.663 & 1.757 \\
& 24 & -0.688 & 0.394 \\
\hline \multirow{2}{*}{175} & 6 & -0.852 & 1.874 \\
& 12 & -0.771 & 1.617 \\
& 24 & -0.796 & 0.183 \\
\hline
\end{tabular}

\subsection{Corrosion Morphology Analysis}

Figure 6 shows the corrosion morphology and corrosion products after electrochemical tests. In Figure 6a, many corrosion pits are distributed on the surface of the alloy, and the depth of corrosion is relatively larger. Meanwhile, some off-white corrosion products and corrosion cracks appear around the corrosion pits. In Figure $6 \mathrm{~b}$, the main elements of the corrosion products are measured as oxygen, aluminum, and chlorine, i.e., $\mathrm{Al}(\mathrm{OH})_{3}$ and $\mathrm{AlCl}_{3}$. The formation of $\mathrm{Al}(\mathrm{OH})_{3}$ is mainly due to the hydrolysis reaction, which is caused by some aluminum ions [56]. The hydrolysis reaction can be expressed as,

$$
\mathrm{Al}^{3+}+3 \mathrm{H}_{2} \mathrm{O} \rightarrow \mathrm{Al}(\mathrm{OH})_{3}+3 \mathrm{H}^{+}
$$




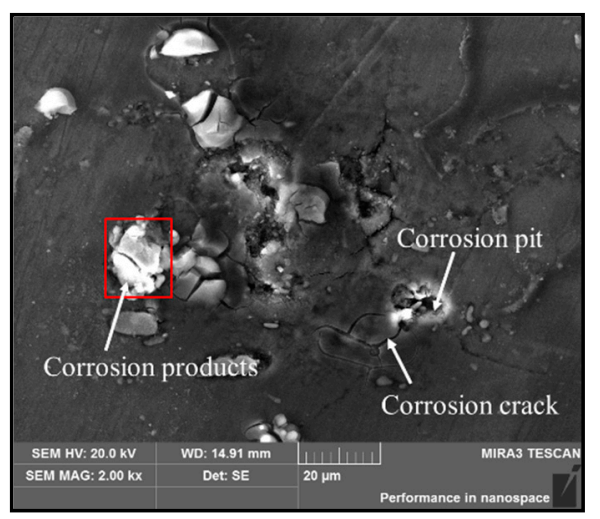

(a)

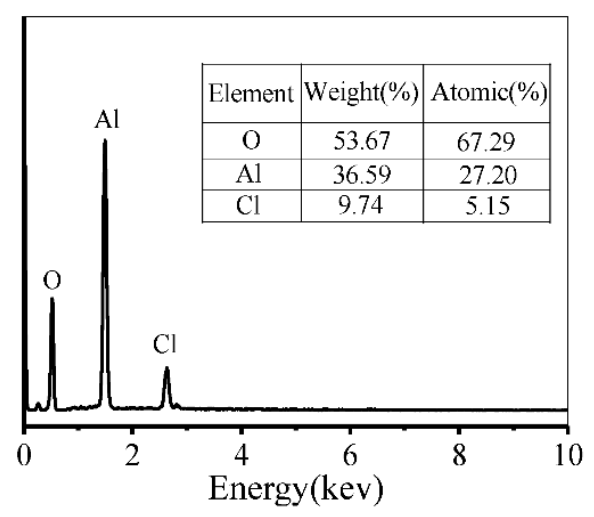

(b)

Figure 6. Corrosion morphology and corrosion products: (a) SEM observation; (b) EDS of corrosion products.

The formation of $\mathrm{AlCl}_{3}$ can be expressed as,

$$
\begin{gathered}
\mathrm{Al}(\mathrm{OH})_{3}+\mathrm{Cl}^{-} \rightarrow \mathrm{Al}(\mathrm{OH})_{2} \mathrm{Cl}+\mathrm{OH}^{-} \\
\mathrm{Al}(\mathrm{OH})_{2} \mathrm{Cl}+\mathrm{Cl}^{-} \rightarrow \mathrm{Al}(\mathrm{OH}) \mathrm{Cl}_{2}+\mathrm{OH}^{-} \\
\mathrm{Al}(\mathrm{OH}) \mathrm{Cl}_{2}+\mathrm{Cl}^{-} \rightarrow \mathrm{AlCl}_{3}+\mathrm{OH}^{-}
\end{gathered}
$$

Corrosion products accumulate on the surface of the alloy during the electrochemical reaction, which inhibits the diffusion of dissolved $\mathrm{Al}^{3+}$. Non-diffusible $\mathrm{Al}^{3+}$ accumulates on the corrosion products, forming a strong electric field [57,58]. Thus, $\mathrm{Cl}^{-}$accumulates to the outer layer of the corrosion products. $\mathrm{Cl}^{-}$can continue to move into the corrosion products due to strong permeability. The corrosion products gradually crack under the combined influence of $\mathrm{Cl}^{-}$and $\mathrm{H}^{+}$, and the matrix under the corrosion product continues to be corroded. The corrosion then mainly proceeds along the crack of the corrosion products.

Figure 7 shows the corrosion morphology and laser confocal maps of the alloy. In Figure 7a,b, a large amount of corrosion products are accumulated on the surface, and the maximum height of the corrosion products reaches $1000 \mu \mathrm{m}$. As the aging time is extended to $24 \mathrm{~h}$, the maximum height of the corrosion products decreases to $550 \mu \mathrm{m}$, as depicted in Figure 7c,d. In Figure 7e,f, many off-white corrosion products are distributed around the corrosion pits for the alloy aged at $175^{\circ} \mathrm{C}$ for $6 \mathrm{~h}$, and the corrosion cracks mainly propagate along the phase boundary. The laser confocal map shows that the maximum height of corrosion products is $900 \mu \mathrm{m}$. In Figure $8 \mathrm{~g}, \mathrm{~h}$, corrosion pits are only found in the center of the surface, and the maximum height of corrosion products decreases to $550 \mu \mathrm{m}$.

OM images of the longitudinal section of the alloy are shown in Figure 8. Generally, the main corrosion types of $\mathrm{Al}-\mathrm{Cu}$ alloys are intergranular and pitting corrosion, and the corrosion type is affected by the microstructures [59-63]. In Figure 8a, the main type of corrosion is intergranular corrosion for the alloy aged at $155^{\circ} \mathrm{C}$ for $6 \mathrm{~h}$. The corrosion area and the corrosion depth are large-, and the maximum corrosion depth is $196 \mu \mathrm{m}$. In addition, the pitting corrosion can be observed at grain boundaries and within grains. As the aging time is increased to $24 \mathrm{~h}$ (Figure 8b), only the pitting corrosion is observed, and the maximum corrosion depth is $32 \mu \mathrm{m}$. In Figure $8 \mathrm{a}, \mathrm{c}$, the corrosion area and depth significantly decrease as the temperature is raised from 155 to $175^{\circ} \mathrm{C}$. As presented in Figure $8 \mathrm{~d}$, a few pits appear on the surface of the alloy aged at $175^{\circ} \mathrm{C}$ for $24 \mathrm{~h}$. The above results indicate that the corrosion type changes from the intergranular corrosion to the pitting corrosion with increasing the aging time and temperature. Meanwhile, the corrosion resistance is also improved with the raised temperature and aging time. 


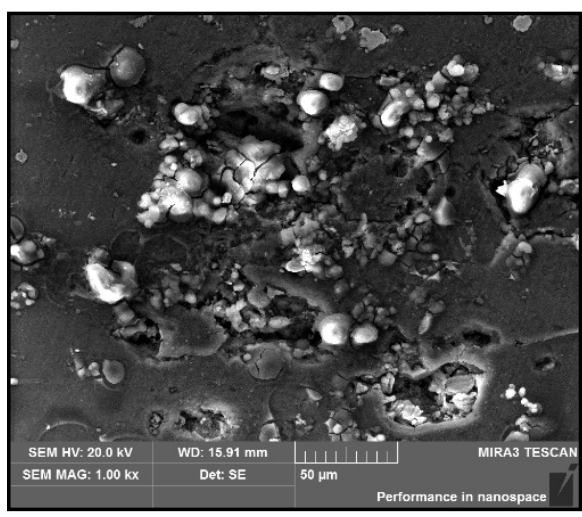

(a)

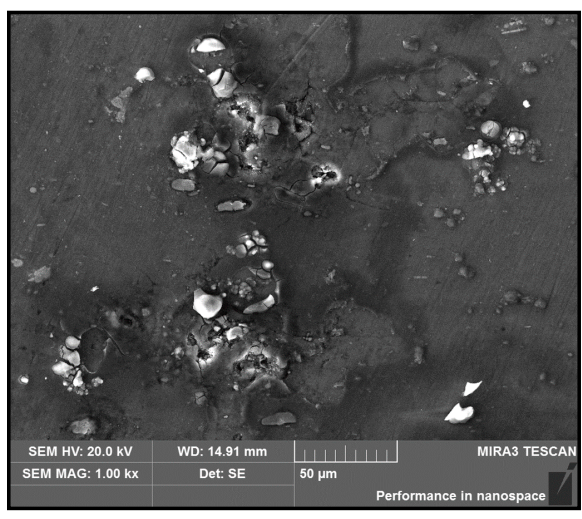

(c)

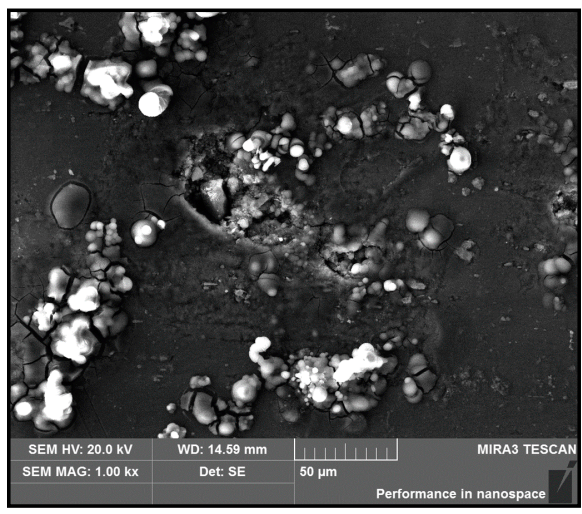

(e)

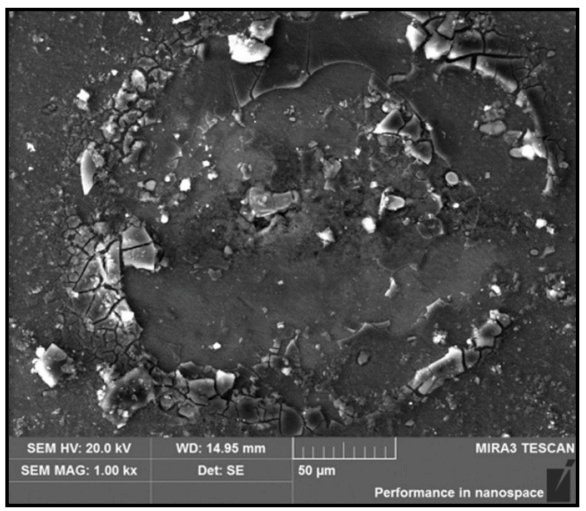

(g)

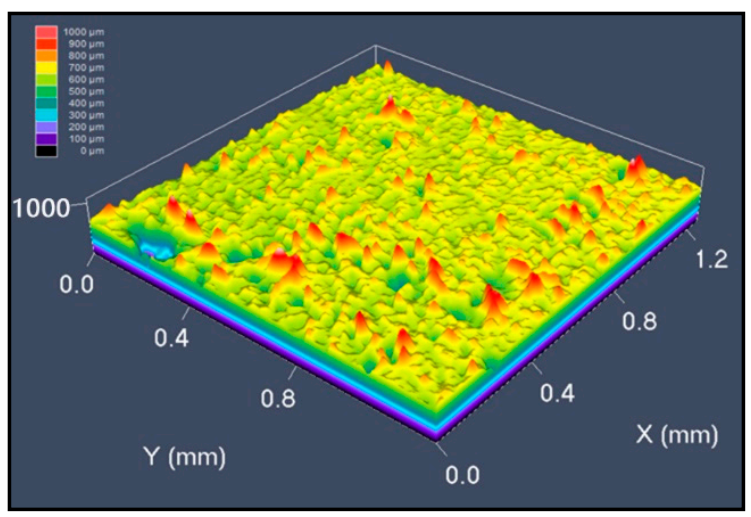

(b)

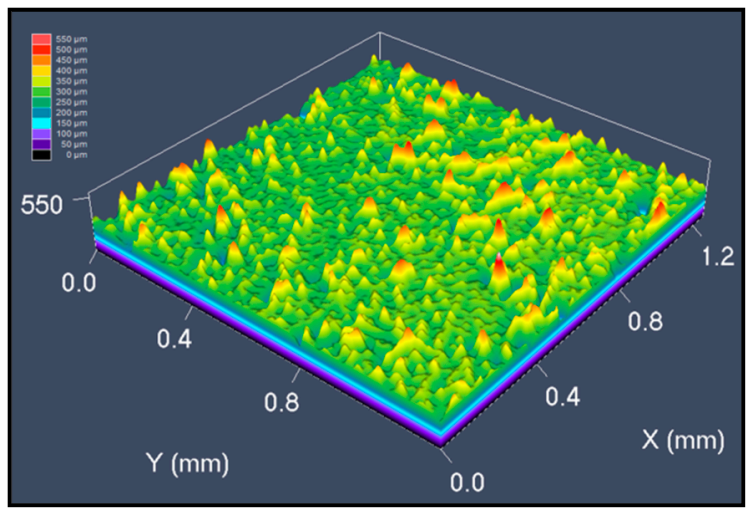

(d)

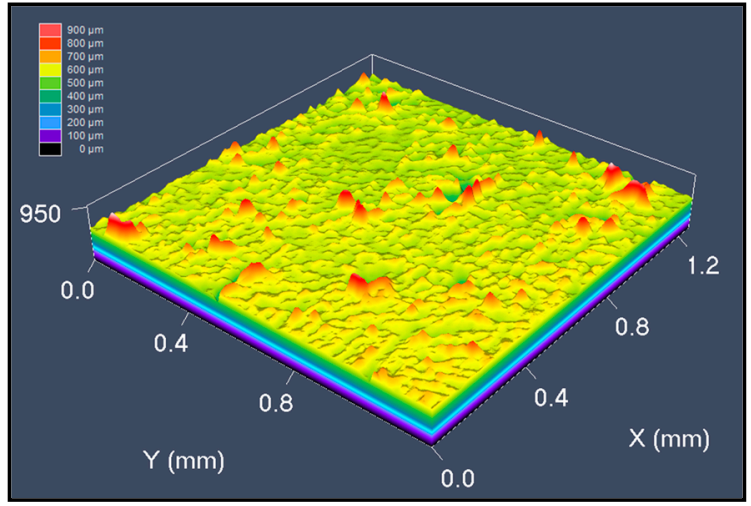

$(\mathbf{f})$

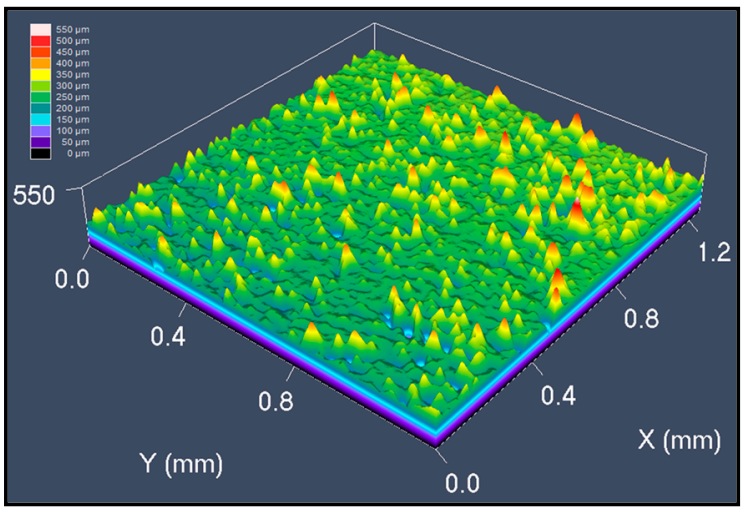

(h)

Figure 7. Corrosion morphology and laser confocal maps at: $(\mathbf{a}, \mathbf{b}) \mathrm{T}=155^{\circ} \mathrm{C}, t=6 \mathrm{~h} ;(\mathbf{c}, \mathbf{d}) \mathrm{T}=155^{\circ} \mathrm{C}, t=24 \mathrm{~h} ;(\mathbf{e}, \mathbf{f}) \mathrm{T}=175^{\circ} \mathrm{C}$, $t=6 \mathrm{~h} ;(\mathrm{g}, \mathrm{h}) \mathrm{T}=175^{\circ} \mathrm{C}, t=24 \mathrm{~h}$. 


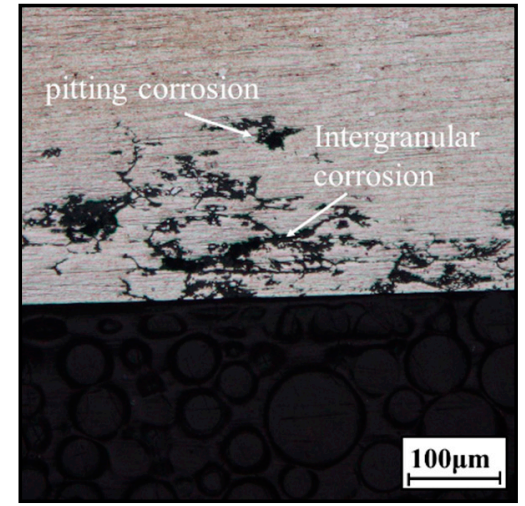

(a)

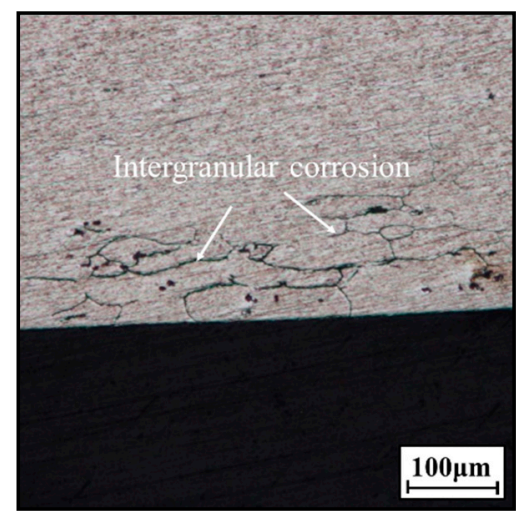

(c)

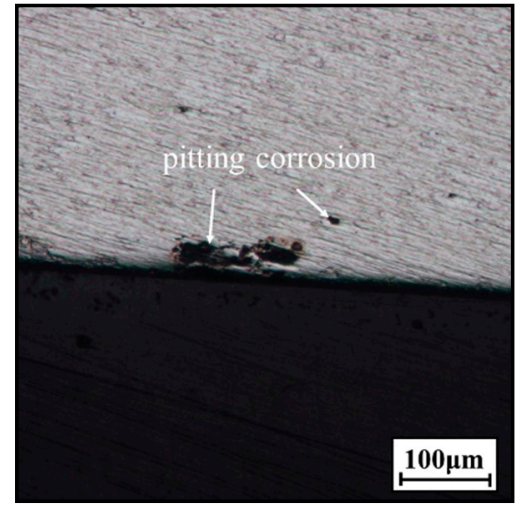

(b)

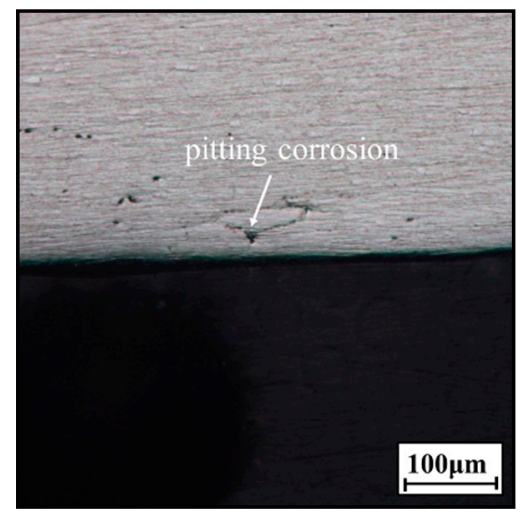

(d)

Figure 8. OM images of longitudinal section of the alloys at: $(\mathbf{a}) \mathrm{T}=155^{\circ} \mathrm{C}, t=6 \mathrm{~h} ;(\mathbf{b}) \mathrm{T}=155^{\circ} \mathrm{C}$, $t=24 \mathrm{~h}$; (c) $175^{\circ} \mathrm{C}, t=6 \mathrm{~h}$; (d) $175^{\circ} \mathrm{C}, t=24 \mathrm{~h}$.

\subsection{Corrosion Mechanism Analysis}

Based on the above experimental results, the main corrosion types of the aged alloy are intergranular and pitting corrosion [64]. Intergranular corrosion is likely to occur in underaged alloys, while the pitting corrosion likely appears in over-aged alloys. Corrosion types are mainly related to the continuity of precipitation phases and the precipitate-free zone (PFZ) at the grain boundaries [65-68]. Figure 9 shows TEM images of grain boundaries of the aged alloy. In Figure 9a, there is no precipitate at the grain boundaries and the $\mathrm{PFZ}$ is narrow for the alloy aged at $155^{\circ} \mathrm{C}$ for $6 \mathrm{~h}$. The grain boundary can accelerate the intergranular corrosion in the corrosion process. This is because the potential difference between the grain boundaries and grains is high, due to the segregation of $\mathrm{Cu}$ atoms. As the aging time is increased to $24 \mathrm{~h}$ (Figure $9 \mathrm{~b}$ ), the discontinuously-distributed precipitates appear at grain boundaries, and there are fine precipitates in the grains. The nucleation and growth of grain boundary precipitates consume a lot of $\mathrm{Cu}$ atoms, which reduces the saturation of solute atoms and promotes the increase of PFZ width. In Figure 9c, the grain boundary precipitates and intragranular precipitates become coarser, and the PFZ becomes wider in the alloy aged at $175^{\circ} \mathrm{C}$ for $24 \mathrm{~h}$. Figure 10 shows the schematic diagram of the evolution of the microstructures. When the alloy is under-aged, the intragranular precipitates are relatively fine, and there are flat PFZs at the grain boundaries. The potential difference between the grain boundaries and grains is high. A coherent circuit is then formed. As such, the alloy exhibits the high sensitivity to intergranular corrosion. When the alloy is over-aged, PFZ becomes more and more wide. In addition, the grain boundary precipitates and intragranular precipitates become more and more coarse. The potential difference decreases and intragranular precipitates make the surrounding matrix prone to dissolution. Moreover, the grain boundary precipitates and PFZ cut corrosion channels in the corrosion process, reducing the corrosion sensitivity of grain boundaries $[45,54,69,70]$. 
Thus, the pitting corrosion is more likely to occur in over-aged alloys. Additionally, the wider PFZ can protect the matrix from corrosion and improve the corrosion resistance of the alloy.

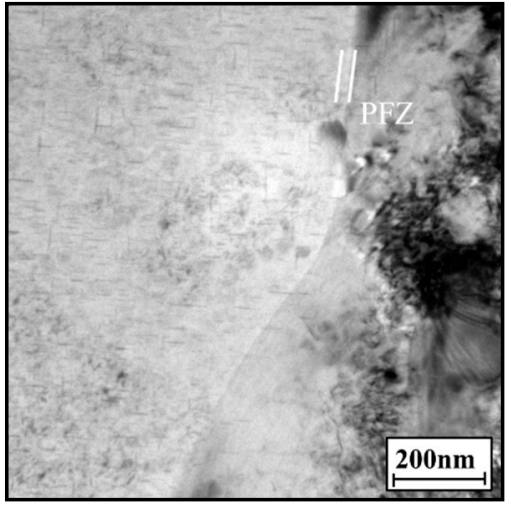

(a)

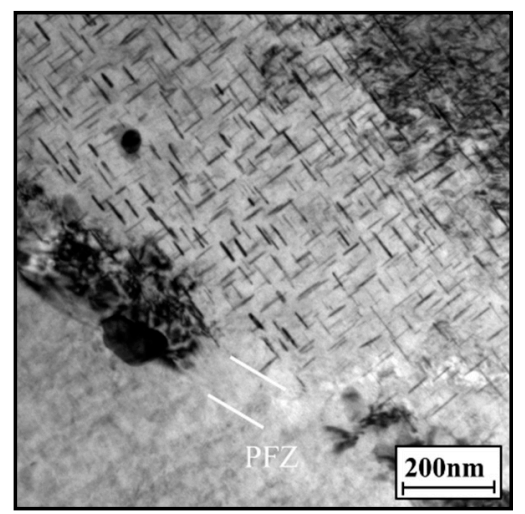

(c)

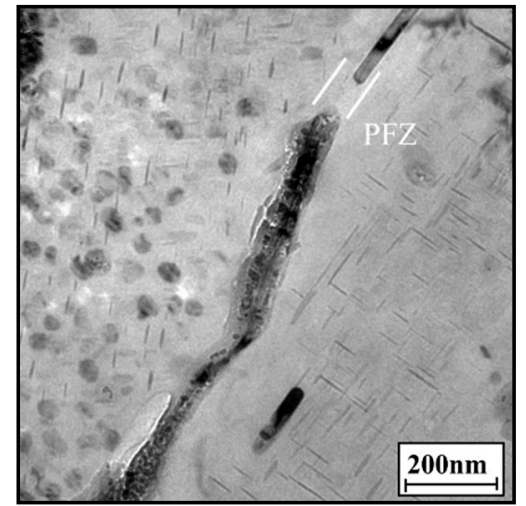

(b)

Figure 9. TEM images of grain boundaries at: (a) $\mathrm{T}=155{ }^{\circ} \mathrm{C}, t=6 \mathrm{~h} ;(\mathbf{b}) \mathrm{T}=155{ }^{\circ} \mathrm{C}, t=24 \mathrm{~h}$; (c) $\mathrm{T}=175^{\circ} \mathrm{C}, t=24 \mathrm{~h}$.

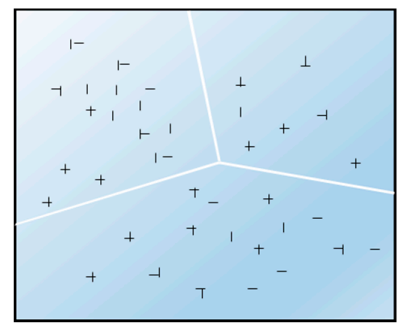

Under-aged

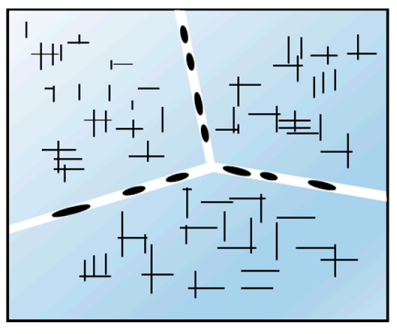

III

$+$

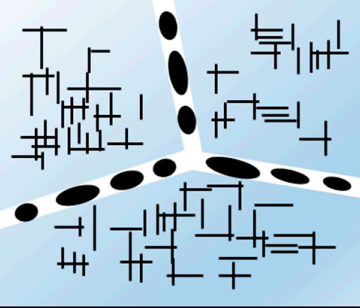

Over-aged

Figure 10. Schematic diagram of microstructure evolution.

\section{Conclusions}

The effects of aging treatment on the corrosion resistance/mechanism of a tensile deformed $\mathrm{Al}-\mathrm{Cu}-\mathrm{Mn}-\mathrm{Fe}-\mathrm{Zr}$ alloy are investigated. Several important conclusions are shown below:

1. The impedance magnitude and polarization resistance increase, while the corrosion current decreases with increasing the aging time and temperature. Therefore, the corrosion resistance is improved.

2. The discontinuously-distributed precipitates and precipitation-free zone, which can cut the corrosion channels, appear at grain boundaries when the temperature is 
relatively high, and the aging time is relatively long. The corrosion sensitivity of grain boundaries can then be reduced.

3. The intergranular corrosion is likely to occur in under-aged alloys. This is because that the potential difference between the grain boundaries and grains is high due to the segregation of $\mathrm{Cu}$ atoms. When the aging degree is increased, the grain boundary precipitates reduce the potential difference, and the intragranular precipitates make the surrounding matrix prone to dissolution. As such, the pitting corrosion is more likely to occur in over-aged alloys.

Author Contributions: Q.T.: Data curation, Investigation, Writing—original draft. Q.-M.Y.: Data curation, Investigation, Writing—review \& editing. Y.-C.L.: Conceptualization, Methodology, Supervision, Writing - review \& editing. J.-Q.W.: Data curation, Investigation. X.-H.Z.: Data curation, Investigation. All authors have read and agreed to the published version of the manuscript.

Funding: This work was supported by the National Natural Science Foundation of China (Grant No. 51775564), and Science and Technology Talent Promotion Project of Hunan Province (Grant No. 2020TJ-Q05), China.

Institutional Review Board Statement: Not applicable.

Informed Consent Statement: Not applicable.

Data Availability Statement: The raw/processed data required to reproduce these findings cannot be shared at this time as the data also forms part of an ongoing study.

Conflicts of Interest: The authors declare that they have no known competing financial interests or personal relationships that could have appeared to influence the work reported in this paper.

\section{References}

1. Tomczyk, A.; Seweryn, A. Fatigue life of EN AW-2024 alloy accounting for creep pre-deformation at elevated temperature. Int. J. Fatigue 2017, 103, 488-507. [CrossRef]

2. Lin, Y.-C.; Luo, S.-C.; Yin, L.-X.; Huang, J. Microstructural evolution and high temperature flow behaviors of a homogenized Sr-modified Al-Si-Mg alloy. J. Alloy. Compd. 2018, 739, 590-599. [CrossRef]

3. Chen, Y.; Liu, C.; Zhou, J.; Wang, F. Effect of alternate corrosion factors on multiaxial low-cycle fatigue life of 2024-T4 aluminum alloy. J. Alloy. Compd. 2019, 772, 1-14. [CrossRef]

4. Li, Y.; Shi, Z.; Lin, J.; Yang, Y.-L.; Rong, Q. Extended application of a unified creep-ageing constitutive model to multistep heat treatment of aluminium alloys. Mater. Des. 2017, 122, 422-432. [CrossRef]

5. Lin, Y.-C.; Wu, Q.; He, D.-G.; Zhu, X.-H.; Liu, D.-Y.; Li, X.-H. Effects of solution time and cooling rate on microstructures and mechanical properties of $2219 \mathrm{Al}$ alloy for a larger spun thin-wall ellipsoidal head. J. Mater. Res. Technol. 2020, 9, 3566-3577. [CrossRef]

6. Murty, S.V.S.N.; Manwatkar, S.K.; Narayanan, P.R. Role of metallographic analysis in the identification of location of crack initiation in a burst tested AA 2219 propellant tank. Metallogr. Microstruct. Anal. 2015, 4, 392-402. [CrossRef]

7. Li, G.-A.; Ma, Z.; Jiang, J.-T.; Shao, W.-Z.; Liu, W.; Zhen, L. Effect of pre-stretch on the precipitation behavior and the mechanical properties of $2219 \mathrm{Al}$ alloy. Materials 2020, 14, 2101. [CrossRef] [PubMed]

8. Zhu, X.-H.; Lin, Y.-C.; Wu, Q.; Jiang, Y.-Q. Effects of aging on precipitation behavior and mechanical properties of a tensile deformed Al-Cu alloy. J. Alloy. Compd. 2020, 843, 155975. [CrossRef]

9. Caltagirone, P.E.; Wheeler, R.W.; Benafan, O.; Bigelow, G.; Karaman, I.; Calkins, F.T.; Kuntz, M.L.; Leal, P.B.C.; Nicholson, D.E.; Ozcan, H.; et al. Shape memory alloy-enabled expandable space habitat-Case studies for second CASMART student design challenge. Shape Mem. Superelast. 2021, 7, 280-303. [CrossRef]

10. Suita, Y.; Takai, D.; Sugiyama, S.; Terajima, N.; Tsukuda, Y.; Fujisawa, S.; Imagawa, K. Welding experiments of aluminum alloy by space GHTA welding at ISS orbital pressure. Trans. Jpn. Soc. Aeronaut. Space Sci. 2005, 48, 71-77. [CrossRef]

11. Agafonov, R.; Vilkov, F.; Kasitsyn, A.; Predko, P.; Marchenkov, A. Aluminum based alloys with rare-earth metals additives application for rocket-and-space engineering. Vestn. Mosk. Aviat. Inst. 2016, 23, 174-180.

12. Lin, Y.-C.; Wang, Z.-W.; He, D.-G.; Zhou, Y.; Chen, M.-S.; Huang, M.-H.; Zhang, J.-L. Effects of pre-treatments on precipitate microstructures and creep-rupture behavior of an Al-Zn-Mg-Cu alloy. J. Mater. Res. 2016, 31, 1286-1295. [CrossRef]

13. Lin, Y.-C.; Liu, G.; Chen, M.-S.; Zhang, J.-L.; Chen, Z.-G.; Jiang, Y.-Q.; Li, J. Corrosion resistance of a two-stage stress-aged Al-Cu-Mg alloy: Effects of external stress. J. Alloys Compd. 2016, 661, 221-230. [CrossRef]

14. Chen, M.-C.; Wen, M.-C.; Chiu, Y.-C.; Pan, T.-A.; Tzeng, Y.-C.; Lee, S.-L. Effect of natural aging on the stress corrosion cracking behavior of A201-T7 aluminum alloy. Materials 2020, 13, 5631. [CrossRef] [PubMed] 
15. Xu, J.; Deng, Y.L.; Chen, J. Enhancing the corrosion resistance of Al-Cu-Li alloys through regulating precipitation. Materials 2020, 13, 2628. [CrossRef]

16. Härtel, M.; Frint, P.; Abstoss, K.G.; Wagner, M.F.-X. Effect of creep and aging on the precipitation kinetics of an Al-Cu alloy after one pass of ECAP. Adv. Eng. Mater. 2018, 20, 1700307. [CrossRef]

17. Lin, Y.-C.; Zhang, J.-L.; Liu, G.; Liang, Y.-J. Effects of pre-treatments on aging precipitates and corrosion resistance of a creep-aged Al-Zn-Mg-Cu alloy. Mater. Des. 2015, 83, 866-875. [CrossRef]

18. Lin, Y.-C.; Xia, Y.-C.; Jiang, Y.-Q.; Zhou, H.-M.; Li, L.-T. Precipitation hardening of 2024-T3 aluminum alloy during creep aging. Mater. Sci. Eng. A 2013, 565, 420-429. [CrossRef]

19. Lin, Y.-C.; Liu, G.; Chen, M.-S.; Li, J.; Zhou, M.; Zhou, H.-M. Effects of two-stage creep-aging processing on mechanical properties of an Al-Cu-Mg alloy. Mater. Des. 2015, 79, 127-135. [CrossRef]

20. Prabhu, T.R. Correlation of deformation strain with the tensile properties and fracture mode of the AA 2014 alloy using simulations and experiments. J. Test. Eval. 2017, 46, 999-1011. [CrossRef]

21. Santecchia, E.; Cabibbo, M.; Ghat, M.; Regev, M.; Spigarelli, S. Physical modeling of the creep response of an Al-Cu-Mg alloy with a fine microstructure transformed by friction stir processing. Mater. Sci. Eng. A 2020, 769, 138521. [CrossRef]

22. Li, G.; Zhou, L.; Luo, L.; Wu, X.; Guo, N. Microstructural evolution and mechanical properties of refill friction stir spot welded alclad 2A12-T4 aluminum alloy. J. Mater. Res. Technol. 2019, 8, 4115-4129. [CrossRef]

23. Wang, W.G.; Wang, G.; Guo, G.N.; Rong, Y.M. Competitive relationship between thermal effect and grain boundary precipitates on the ductility of an as-quenched Al-Cu-Mn alloy. Int. J. Damage Mech. 2018, 27, 779-798. [CrossRef]

24. Fernández, R.; Bokuchava, G.; Toda-Caraballo, I.; Bruno, G.; Turchenko, V.; Gorshkova, J.; González-Doncel, G. Analysis of the combined strengthening effect of solute atoms and precipitates on creep of aluminum alloys. Adv. Eng. Mater. 2020, $22,1901355$. [CrossRef]

25. Lin, Y.-C.; Jiang, Y.-Q.; Xia, Y.-C.; Zhang, X.-C.; Zhou, H.-M.; Deng, J. Effects of creep-aging processing on the corrosion resistance and mechanical properties of a typical Al-Cu-Mg alloy. Mater. Sci. Eng. A 2014, 605, 192-202. [CrossRef]

26. Li, Y.-D.; Zhang, Y.; Li, S.-M.; Zhao, P.-Z. Influence of adipic acid on anodic film formation and corrosion resistance of 2024 aluminum alloy. Trans. Nonferr. Met. Soc. 2016, 26, 492-500. [CrossRef]

27. Araujo, J.V.d.; Milagre, M.X.; Ferreira, R.O.; Machado, C.d.C.; Bugarin, A.d.S.; Ma-chado, I.F.; Costa, I. Exfoliation and intergranular corrosion resistance of the $2198 \mathrm{Al}-\mathrm{Cu}-\mathrm{Li}$ alloy with different thermomechanical treatments. Mater. Corros. 2020, 71, 1957-1970. [CrossRef]

28. Wang, J.; Zhang, B.; Wu, B.; Ma, X. Size-dependent role of S phase in pitting initiation of 2024Al alloy. Corros. Sci. 2016, 105, 183-189. [CrossRef]

29. Ma, S.; Zhao, Y.; Zou, J.; Yan, K.; Liu, C. The effect of laser surface melting on microstructure and corrosion behavior of friction stir welded aluminum alloy 2219. Opt. Laser Technol. 2017, 96, 299-306. [CrossRef]

30. Liu, Z.; Chong, P.H.; Skeldon, P.; Hilton, P.A.; Spencer, J.T.; Quayle, B. Fundamental understanding of the corrosion performance of laser-melted metallic alloys. Surf. Coat. Technol. 2006, 200, 5514-5525. [CrossRef]

31. Surekha, K.; Murty, B.; Rao, K.P. Effect of processing parameters on the corrosion behaviour of friction stir processed AA 2219 aluminum alloy. Solid State Sci. 2009, 11, 907-917. [CrossRef]

32. Lu, Y.; Wang, J.; Li, X.; Li, W.; Li, R.; Zhou, D. Effects of pre-deformation on the microstructures and corrosion behavior of 2219 aluminum alloys. Mater. Sci. Eng. A 2018, 723, 204-211. [CrossRef]

33. Huang, J.L.; Li, J.F.; Liu, D.Y.; Zhang, R.F.; Chen, Y.L.; Zhang, X.H.; Ma, P.C.; Gupta, R.K.; Birbilis, N. Correlation of inter-granular corrosion behaviour with microstructure in Al-Cu-Li alloy. Corros. Sci. 2018, 139, 215-226. [CrossRef]

34. Grilli, R.; Baker, M.A.; Castle, J.E.; Dunn, B.; Watts, J.F. Localized corrosion of a 2219 aluminium alloy exposed to a $3.5 \% \mathrm{NaCl}$ solution. Corros. Sci. 2010, 52, 2855-2866. [CrossRef]

35. Chen, Y.; Zhou, J.; Liu, C.; Wang, F. Effect of pre-deformation on the pre-corrosion multiaxial fatigue behaviors of 2024-T4 aluminum alloy. Int. J. Fatigue 2018, 108, 35-46. [CrossRef]

36. Hikku, G.; Jeyasubramanian, K.; Venugopal, A.; Ghosh, R. Corrosion resistance behaviour of graphene/polyvinyl alcohol nanocomposite coating for aluminium-2219 alloy. J. Alloy. Compd. 2017, 716, 259-269. [CrossRef]

37. Kairy, S.K.; Rouxel, B.; Dumbre, J.; Lamb, J.; Langan, T.J.; Dorin, T.; Birbilis, N. Simultaneous improvement in corrosion re-sistance and hardness of a model 2xxx series Al-Cu alloy with the microstructural variation caused by Sc and Zr additions. Corros. Sci. 2019, 158, 108095. [CrossRef]

38. Zhu, Z.; Deng, C.; Wang, Y.; Yang, Z.; Ding, J.; Wang, D. Effect of post weld heat treatment on the microstructure and corrosion behavior of AA2219 aluminum alloy joints welded by variable polarity tungsten inert gas welding. Mater. Des. 2015, 65, 1075-1082. [CrossRef]

39. Emarati, S.M.; Mozammel, M. Theoretical, fundamental and experimental study of liquid-repellency and corrosion resistance of fabricated superamphiphobic surface on Al alloy 2024. Chem. Eng. J. 2020, 387, 124046. [CrossRef]

40. Simsek, I.; Nalcacioglu, C.; Ozyurek, D. The effects of aging temperature on the corrosion and electrical conductivity in the AA7075 alloy produced by powder metallurgy method. Acta Phys. Pol. A 2019, 135, 722-725. [CrossRef]

41. Shi, T.; Li, X.; Zhang, Q.; Li, B. One-step potentiostatic deposition of micro-particles on Al alloy as superhydrophobic surface for enhanced corrosion resistance by reducing interfacial interactions. Coatings 2018, 8, 392. [CrossRef] 
42. Yang, Q.; Zhou, Y.; Li, Z.; Mao, D. Effect of hot deformation process parameters on microstructure and corrosion behavior of 35CrMoV steel. Materials 2019, 12, 1455. [CrossRef] [PubMed]

43. Soleimani, M.; Mirzadeh, H.; Dehghanian, C. Processing route effects on the mechanical and corrosion properties of dual phase steel. Met. Mater. Int. 2020, 26, 882-890. [CrossRef]

44. Sun, Y.; Pan, Q.; Sun, Y.; Wang, W.; Huang, Z.; Wang, X.; Hu, Q. Localized corrosion behavior associated with Al7Cu2Fe intermetallic in Al-Zn-Mg-Cu-Zr alloy. J. Alloy. Compd. 2019, 783, 329-340. [CrossRef]

45. Lin, Y.-C.; Zhang, J.-L.; Chen, M.-S.; Zhou, Y.; Ma, X. Electrochemical corrosion behaviors of a stress-aged Al-Zn-Mg-Cu alloy. J. Mater. Res. 2016, 31, 2493. [CrossRef]

46. Xu, L.; Zhang, J.; Han, Y.; Zhao, L.; Jing, H. Insights into the intergranular corrosion of overlay welded joints of X65-Inconel 625 clad pipe and its relationship to damage penetration. Corros. Sci. 2019, 160, 108169. [CrossRef]

47. Fadaee, H.; Javidi, M.M. Investigation on the corrosion behaviour and microstructure of 2024-T3 Al alloy treated via plasma electrolytic oxidation. J. Alloy. Compd. 2014, 604, 36-42. [CrossRef]

48. Shaik, M.A.; Syed, K.H.; Golla, B.R. Electrochemical behavior of mechanically alloyed hard Cu-Al alloys in marine environment. Corros. Sci. 2019, 153, 249-257. [CrossRef]

49. Soleimani, M.; Mirzadeh, H.; Dehghanian, C. Effects of spheroidization heat treatment and intercritical annealing on mechanical properties and corrosion resistance of medium carbon dual phase steel. Mater. Chem. Phys. 2021, 257, 123721. [CrossRef]

50. Shi, W.; Zhou, H.; Zhang, X. High-strength and anti-corrosion of Al-Cu-Mg alloy by controlled ageing process. Philos. Mag. Lett. 2019, 99, 235-242. [CrossRef]

51. Lin, Y.-C.; Jiang, Y.-Q.; Zhang, J.-L.; Chen, X.-M. Influence of stress-aging processing on precipitates and mechanical properties of a 7075 aluminum alloy. Adv. Eng. Mater. 2018, 20, 1700583. [CrossRef]

52. Deng, Y.L.; Yin, Z.M.; Zhao, K.; Duan, J.Q.; Hu, J.; He, Z.B. Effects of Sc and Zr microalloying additions and aging time at $120 \mathrm{C}$ on the corrosion behaviour of an Al-Zn-Mg alloy. Corros. Sci. 2012, 65, 288-298. [CrossRef]

53. Wen, D.; Long, P.; Li, J.; Huang, L.; Zheng, Z. Effects of linear heat input on microstructure and corrosion behavior of an austenitic stainless steel processed by wire arc additive manufacturing. Vacuum 2020, 173, 109131. [CrossRef]

54. Lin, Y.-C.; Liu, G.; Chen, M.-S.; Huang, Y.-C.; Chen, Z.-G.; Ma, X.; Jiang, Y.-Q.; Li, J. Corrosion resistance of a two-stage stress-aged Al-Cu-Mg alloy: Effects of stress-aging temperature. J. Alloy. Compd. 2016, 657, 855-865. [CrossRef]

55. Khan, M.A.; Wang, Y.; Anjum, M.J.; Yasin, G.; Malik, A.; Nazeer, F.; Khan, S.; Ahmad, T.; Zhang, H. Effect of heat treatment on the precipitate behaviour, corrosion resistance and high temperature tensile properties of 7055 aluminum alloy synthesis by novel spray deposited followed by hot extrusion. Vacuum 2020, 174, 109185. [CrossRef]

56. Zhan, X.; Tang, J.; Li, H.; Liang, X.; Lu, Y.; Che, Y.; Tu, W.; Zhang, Y. Effects of non-isothermal aging on mechanical properties, corrosion behavior and microstructures of Al-Cu-Mg-Si alloy. J. Alloy. Compd. 2020, 819, 152960. [CrossRef]

57. Azarniya, A.; Taheri, A.K.; Taheri, K.K. Recent advances in ageing of 7xxx series aluminum alloys: A physical metallurgy perspective. J. Alloy. Compd. 2019, 781, 945-983. [CrossRef]

58. Shao, L.; Li, H.; Jiang, B.; Liu, C.; Gu, X.; Chen, D. A comparative study of corrosion behavior of hard anodized and micro-arc oxidation coatings on 7050 aluminum alloy. Metals 2018, 8, 165. [CrossRef]

59. Saillard, R.; Viguier, B.; Odemer, G.; Pugliara, A.; Fori, B.; Blanc, C. Influence of the microstructure on the corrosion behaviour of 2024 aluminium alloy coated with a trivalent chromium conversion layer. Corros. Sci. 2018, 142, 119-132. [CrossRef]

60. Ferri, M.; Trueba, M.; Trasatti, S.; Cabrini, M.; Conte, A.L. Electrochemical investigation of corrosion and repassivation of structural aluminum alloys under permanent load in bending. Corros. Rev. 2017, 35, 225-239. [CrossRef]

61. Trueba, M.; Trasatti, S. The repassivation response from single cycle anodic polarization: The case study of a sensitized Al-Mg alloy. Electrochim. Acta 2018, 259, 492-499. [CrossRef]

62. Sun, S.; Fang, Y.; Zhang, L.; Li, C.; Hu, S. Effects of aging treatment and peripheral coarse grain on the exfoliation corrosion behaviour of 2024 aluminium alloy using SR-CT. J. Mater. Res. Technol. 2020, 9, 3219-3229. [CrossRef]

63. Su, R.; Wang, K.; Yang, Y.; Qu, Y.; Li, R. Effect of Mg content on the microstructure and corrosion properties of Al-Cu-Mn alloy. J. Mater. Eng. Perform. 2020, 29, 1622-1629. [CrossRef]

64. Kaithwas, C.; Bhuyan, P.; Pradhan, S.; Mandal, S. Microstructure evolution during low-strain thermo-mechanical processing and its repercussion on intergranular corrosion in alloy 600H. Mater. Charact. 2018, 145, 582-593. [CrossRef]

65. Pradhan, S.; Bhuyan, P.; Mandal, S. Individual and synergistic influences of microstructural features on intergranular corrosion behavior in extra-low carbon type 304L austenitic stainless steel. Corros. Sci. 2018, 139, 319-332. [CrossRef]

66. Deepak, K.; Mandal, S.; Athreya, C.N.; Kim, D.I.; Boer, B.D.; Sarma, V.S. Implication of grain boundary engineering on high temperature hot corrosion of alloy 617. Corros. Sci. 2016, 106, 293-297.

67. Wang, Z.; Chen, P.; Li, H.; Fang, B.; Song, R.; Zheng, Z. The intergranular corrosion susceptibility of $2024 \mathrm{Al}$ alloy during re-ageing after solution treating and cold-rolling. Corros. Sci. 2017, 114, 156-168. [CrossRef]

68. Li, B.; Pan, Q.-L.; Chen, C.-P.; Yin, Z. Effect of aging time on precipitation behavior, mechanical and corrosion properties of a novel Al-Zn-Mg-Sc-Zr alloy. Trans. Nonferr. Met. Soc. 2016, 26, 2263-2275. [CrossRef]

69. Du, J.; Ding, D.; Zhang, W.; Xu, Z.; Gao, Y.; Chen, G.; You, X.; Chen, R.; Huang, Y.; Tang, J. Effect of Ce addition on the microstructure and properties of Al-Cu-Mn-Mg-Fe lithium battery shell alloy. Mater. Charact. 2018, 142, 252-260. [CrossRef]

70. Huang, L.; Chen, K.; Li, S. Influence of grain-boundary pre-precipitation and corrosion characteristics of inter-granular phases on corrosion behaviors of an Al-Zn-Mg-Cu alloy. Mater. Sci. Eng. B 2012, 177, 862-868. [CrossRef] 